Magdalena Brodacka

Uniwersytet Jagielloński

magdalenabrodacka@gmail.com

\title{
Budowniczy empatii
}

(Krzysztof Czyżewski, Małe centrum świata. Zapiski praktyka idei, Fundacja Pogranicze, Sejny 2017, ss. 248)

\section{Empathy Builder}

Godzi naukę ze sztuką, pracę u podstaw z działalnością artystyczną. Pobudza do działania, rozumnego niesienia pomocy tym, którzy sami nie potrafią zbudować żadnego mostu. Krzysztof Czyżewski, założyciel ośrodka „Pogranicze” w Sejnach wydał właśnie zbiór esejów Mate centrum świata. Zapiski praktykaidei. To kolejna po Ścieżce pogranicza (2001), Linii powrotu. Zapiski z pogranicza (2008) oraz Mitosz. Tkanka tączna (2014) pozycja ugruntowująca myśli i słownik autora. Czyżewski nie diagnozuje kondycji coraz bardziej wątłej Europy, nie epatuje też apokaliptycznymi wizjami rozpadu, których ostatnio nie brak. W swojej najnowszej książce nie zmienia sposobu narracji ani języka. Wprost przeciwnie - przedstawia siebie i swoją wizję świata, którą już dobrze znamy z jego poprzednich książek. Czternaście esejów składających się na Mate centrum świata znanych jest już na ogół z publikacji na łamach czasopism. Autor dokonał ich wyboru i ułożył chronologicznie w trzy części: wprowadzający Etos amatora i teksty z lat dziewięćdziesiątych oraz pierwszej dekady XXI wieku, następnie umieścił zwornikowy esej-poemat Ścieżka pogranicza i zbiór tekstów z ostatnich lat. Całości dopełnia syntetyczny tekst Przemysława Czaplińskiego Pogranicznik. Tytuł Mate centrum świata. Zapiski praktyka idei zawiera klucze, którymi Czyżewski otwiera kolejne rozdziały książki - kierunki, wedle których orientuje swoje inicjatywy. Igła jego kompasu wskazuje na praktykę, ideę, most i empatię. A w samym środ$\mathrm{ku}$ jest on - amator pogranicza.

W 1991 roku Czyżewski razem ze swoją żoną i przyjaciółmi założył w Sejnach ośrodek „Pogranicze - sztuk, kultur, narodów”. Właśnie wówczas nastał czas wielkich przemian i równie wielkich nadziei - był to czas odzyskany, 
gdyż, jak pisze autor -,,odzyskiwaliśmy dla siebie przyszłość” ${ }^{1}$. To, co w poprzednich latach obrastało w martwą tkankę, na początku lat dziewięćdziesiątych mogło uwolnić swój potencjał, hamowane siły i nadmiar miłości. Amator to bowiem człowiek, który ma w sobie zbyt wiele miłości, wybiera ścieżki nieoczywiste, nie przynależy do głównego nurtu, a swoje wewnętrzne centrum lokuje gdzieś na pograniczu. „Szczęście zatem jest konsekwencją umiejętności rozpoznania swojego głosu wewnętrznego" (s. 9). Czyżewski od razu na początku podkreśla i dowartościowuje etos amatora, który w dzisiejszych czasach przyjęło się rozpatrywać $\mathrm{w}$ sensie negatywnym, jako proste przeciwieństwo profesjonalizmu. Amator nie obiera dobrze znanych i utartych dróg (bo cóż za drogi prowadzą do Krasnogrudy, na Wschód czy Bałkany), oddala się od wielkomiejskiego centrum, bo przecież centrum świata może być wszędzie. Czyżewski, wybierając wyjątkowe ścieżki, wybiera tym samym wyjątkowy ogląd prowincji, na którą patrzy z czułością i nadzieją. Spojrzenie to gwarantuje wyzwolenie twórczego potencjału danego miejsca. Autor, kreśląc obraz świata, świadomie nawiązuje do tradycji romantycznej, powołuje się przy tym na swoich wielkich mistrzów - Czesława Miłosza i Marię Janion. Romantyzm jest dla Czyżewskiego świadomym podążaniem w głąb siebie. A im głębiej schodzimy, tym więcej zawiłości i nieoczywistości odkrywamy do tej podróży zachęca czytelnika. Jego poetycki styl przypomina trochę pejzaż nowo odkrytej, idyllicznej prowincji, ale stawia pytania zasadnicze: czego nie zdołaliśmy ocalić i naprawić? Co zostało wyparte i zapomniane? Ile mostów zburzyliśmy, a ilu ciagle nie udało się zbudować?

Czyżewski nie bawi się w psychoanalityka Polaków, czy szerzej - Europejczyków. To raczej wytrawny gracz w szklane paciorki, które stają się stylem i sensem życia. A jest to gra niezwykle odpowiedzialna, wymagająca cierpliwości i prawdziwej mądrości, do której ciągle się dojrzewa. Autor przestrzega przed polaryzacją rzeczywistości, niuansuje każde zagadnienie i problem. Wydarzenia po 1989 roku w Polsce i w całej Europie Srodkowej (do której zalicza również Wschód i Bałkany) nie uwolniły nas od czarno-białego myślenia. Czyżewski uwrażliwia na biegunowe ujęcie świata: od komunizmu po kosmopolityzm, od wytaczania granic po ich zupełne zniesienie, od wspólnoty europejskiej po nacjonalizm pojedynczych państw. A wystarczy, jak się wydaje po lekturze esejów Czyżewskiego, zadawać pytania, krytycznie myśleć i budować. Słowo Bildung pojawia się wielokrotnie w Matym centrum świata. Z jednej strony trąci myszką i przywołuje na myśl nieprzystające do współczesności ideały, a z drugiej - paradoksalnie otwiera w człowieku potencjał tworzenia, realizowania marzeń, projektów, wcielenia w życie niemożliwego, czy wręcz wymyślania niepomyślanego. Tym jest tytułowy praktyk idei - budowniczym, który odzyskuje utracony czas i zwraca myślenie ku przyszłości.

${ }^{1}$ K. Czyżewski, Mate centrum świata. Zapiski praktyka idei, Sejny 2017, s. 142; wszystkie cytaty z tego wydania. 
Sposób opisywania czasu, jego postrzegania, do którego skłania czytelnika, jest jednym z najbardziej interesujących zagadnień całego zbioru esejów. To temporalność zakorzeniona w późnoromantycznej wizji, ocalała z komunistycznej inercji, zatrzymująca się na pograniczu państw, kultur i narodów, po to, by otworzyć w człowieku potencjał uważności. Szczególna uwaga skupiona na innych, empatia amatora są fundamentem, od którego należy zacząć budowę mostu. „Most jest jak nitka wielkiej tkaniny opowieści, którą po zerwaniu trzeba na nowo zawiązywać, szukać dla niej pogubionego splotu i miejsca, które zestraja się z kompozycją wzoru" (s. 186). Czyżewski częściej niż o zadomowieniu i byciu u siebie pisze właśnie o moście i kulturze połączenia. Jest ostrożny w szafowaniu słowami wspólnota i jedność. Szanuje różnorodność, której podstawę stanowi poczucie odrębności każdej jednostki, a za odrębnością idzie świadomość granic własnego domostwa - bycia wolnym i jedynym, ponieważ „paradoksalnie - to zbudowanie czterech ścian z dachem nad własną głową stwarza dopiero autentyczną możliwość otwarcia, przełamania izolacji i gotowości na spotkanie z innym" (s. 72). Spełnienie i poszanowanie tego wymogu umożliwia integrację, a co za tym idzie - Bildung wspólnych interesów, potrzeb, marzeń. Na każdym etapie wielkiej historii tęsknoty człowieka są inne, czas je zmienia i uniemożliwia proste powroty do przeszłości. Nasza tęsknota, jak mówi Czyżewski, ma kształt koła, linia prosta nie istnieje. Jest to niezmiernie istotne w świetle ostatnich przemian w Europie wojny na Ukrainie, deklaracji współpracy wyszehradzkiej, upraszczającej tęsknoty za tym, co było kiedyś, odradzania się nacjonalizmów czy wyodrębniania nie-wspólnych interesów w postaci Brexitu. Neimar - po bałkańsku budowniczy mostów - jest człowiekiem słowa. Dodajmy, cierpliwym człowiekiem słowa, świadomym każdego najmniejszego kamienia położonego pod budowę mostu-dialogu. Krzysztof Czyżewski nazywa siebie neimarem i konsekwentnie, czerpiąc z tradycji Martina Heideggera, przeciwstawia się zapomnieniu bycia. A o byciu najłatwiej zapomnieć tam, gdzie nie pojawia się żaden most, żaden ośrodek kultury, żadne próby animacji kulturowej społeczeństwa. Warsztat, który buduje Czyżewski, opiera się na kształceniu i nauce znaczenia słów: pogranicze, agora, neimar, tkanka łączna, krytyczny patriotyzm.

By w pełni pojąć złożony i wielowymiarowy projekt-ideę Krzysztofa Czyżewskiego, niezbędne jest przyswojenie sobie jego słownika i zrozumienie, choćby częściowe, niezwykłej wrażliwości samego autora. Trochę na przekór wszelkim zawirowaniom i przemianom w Europie i na świecie proponuje on czytelnikowi spokojną narrację i znajomo brzmiący, jemu właściwy słownik amatora pogranicza. Uwydatnia znaczenie słów-kluczy charakterystycznych dla jego wizji świata, uczy odbiorcę ich użycia i w końcu uwrażliwia na odpowiedzialność za słowo. To, jak nazywamy siebie i rzeczywistość, mówi o nas samych. Dla tych, którzy czytali jego wcześniejsze książki i zapoznali się z bogatym dorobkiem artystycznym, odnalezienie się w gęstym i poetyckim języku zapisków nie będzie stanowiło problemu. Inaczej mogą natomiast pomyśleć 
ci, którzy dotychczas nie byli przyzwyczajeni do mówienia o sprawach zasadniczych dla Europy językiem poezji i metafory. Czyżewski przyznaje się do tradycji Czesława Miłosza, fascynacji jego poezją i ogromnym dorobkiem myślowym. To jego ustanawia patronem pogranicza, podkreślając jednocześnie wpływ paryskiej „Kultury” na własny rozwój intelektualny i duchowy. Nie da się jednak ukryć, że informacje te zawarł już w poprzednich książkach. Mate centrum świata stanowi powtórzenie i przetworzenie wielu wcześniejszych zapisków autora. Poza opisem własnej działalności (jej sens należy nieustannie czytelnikom przypominać) Czyżewski wprowadza interesującą koncepcję Europy ojczyzn, która mogłaby stanowić odpowiedź na coraz bardziej pogrążającą się w napięciach Europę wspólnoty. Wielokulturowość, według autora, przeżywa kryzys, tak samo jak kultura europejska. Wspólny dialog niknie w świetle egoizmu nacjonalizmów. Myśli polityczne, które inicjuje Czyżewski, są z pewnością niezwykle interesujące, trafne, gdyż zbudowane na wieloletnim doświadczaniu życia w Europie Środkowej, sam autor jednak nie analizuje ich wystarczająco głęboko. Przeczuwa zmiany, nawołuje do wyboru narracji, która „będzie zdolna stworzyć przeciwwagę dla mitów narodowych” (s. 156). Pytanie brzmi, czy założyciel „Pogranicza” chce podążać za coraz gwałtowniejszymi i niejednoznacznymi w ocenie przemianami, które obecnie dokonują się niemal w każdym zakątku świata, a szczególnie w Europie. Mate centrum świata, trochę wbrew „odzyskiwaniu dla kultury czasu” (s. 145), jest książką przede wszystkim o przeszłości. Teraźniejszość wydaje się zbyt niejednoznaczna i zbyt dynamiczna, by można było przyszpilić ją choć na chwilę, zatrzymać w biegu i zdiagnozować. Autor konsekwentnie obraca się wokół wypracowanego przed wieloma laty słownika, który nie stracił aktualności, ale z pewnością wymaga uzupełnień. Wszelkie bowiem afery informacyjne, ideologie postprawdy i trochę alternatywny świat internetowej „chmury” niebezpiecznie zawłaszczają, a z pewnością przekształcają to, co zostało nazwane ponad 20 lat temu.

Kompas Krzysztofa Czyżewskiego jest niezwykle czuły zwłaszcza na ludzką krzywdę i przemilczenia. Od 1989 roku, momentu narodzin nadziei i realnej możliwości budowania mostów w Europie Środkowo-Wschodniej, zdarzyło się zbyt wiele złego i niepokojącego, by o tym nie mówić. Czyżewski służy słowu, ale takiemu, które będzie mogło poruszyć w odbiorcy pokłady empatii, gdyż bez niej każda działalność - naukowa, społeczna, polityczna - jest skazana na niepowodzenie. Lektura esejów zgromadzonych w Matym centrum świata uczy wrażliwości amatora, tak szczególnie dzisiaj potrzebnej. To, co funduje nam teraz rzeczywistość, może się okazać nie do zniesienia i nie do zrozumienia zwłaszcza dla tych, którzy po transformacji ustrojowej spodziewali się lepszego jutra. Lepsze jutro ciągle jest możliwe - tak długo, jak (współ)czucie i realne działania Bildung będą szły ze sobą w parze. Dopóty, dopóki Krzysztof Czyżewski będzie nas na to uwrażliwiał swoją zbyt wielką miłością do małego centrum świata. 